\title{
The number and activity of mammary epithelial cells, determining factors for milk production
}

\author{
Marion BouTINAUD ${ }^{\mathrm{a} *}$, Jocelyne GUINARD-FLAMENT ${ }^{\mathrm{a}}$, Hélène JAMMES ${ }^{\mathrm{b}}$ \\ a INRA-Agrocampus, UMR sur la Production du Lait, 35590 St-Gilles, France \\ b INRA, Neurobiologie de l'olfaction et prise alimentaire, 78352 Jouy-en-Josas, France
}

\begin{abstract}
The ability of ruminant mammary glands to produce milk is determined by the number of cells secreting milk and their level of activity. Changes in the number of cells in the udder occur during lactation. It has been shown that mammary cells proliferate during this process, while other cells die through apoptosis. The decline in milk production after peak lactation appears to be due to a gradual reduction in the number of milk-secreting cells, either through cell death or by the abrasion of epithelial cells during milk ejection. Other factors are also known to modify cell turnover in the udder, such as reproductive status, growth hormone treatment or milking frequency and nutrition. A description of the effects of husbandry practices makes it possible to envisage different processes for mammary tissue regeneration during lactation. Indeed, changes in milking frequency are capable of modifying the number of epithelial cells in an alveolus, while GH treatment acts on the total number of alveoli. Thus recent studies have demonstrated an heterogeneity of the processes of proliferation and cell death within the mammary gland. However, unanswered questions still remain concerning the presence of stem cells in ruminants, the lifespan of mammary epithelial cells or the relative rate of loss of mammary cells due to apoptosis and epithelial abrasion.
\end{abstract}

ruminant / milk production / mammary gland / mammary cells / proliferation / apoptosis

\section{INTRODUCTION}

The mammary gland is made up of a tubulo-alveolar epithelium. Even though this epithelium comprises different types of accessory cells, such as adipocytes, fibroblasts, myoepithelial cells and endothelial cells, it is mainly composed of epithelial cells organised into alveoli. Milk is synthesised within these epithelial cells. It is then secreted into the alveolar lumen and transported via a network of ducts towards the gland cistern. A mammary gland's ability to produce milk is determined by the number of secreting cells and their level of activity. The mammary gland is an organ whose secreting tissue develops as a function of gestation-lactation cycles. Variations in the number of mammary cells mainly occur during gestation, but also during lactation. Changes in cell number during lactation may be responsible for variations in milk yield. Indeed, the decline in milk production following peak lactation appears to be due to a gradual reduction in the number of milk-secreting cells. Furthermore, changes in cell activity may be involved in variations in milk yield, as a function of milking frequency. However, the phenomena involved in changes in the number and activity of mammary cells are not yet fully

\footnotetext{
* Corresponding author: Marion.Boutinaud@ rennes.inra.fr
} 
understood. It seems necessary to take stock of the knowledge available on how changes occur to the number and activity of mammary cells. The current challenge is thus to better understand the mechanisms controlling cell turnover in the mammary gland, since this determines the quantity of secreting tissue for the production of milk, as well as evaluating the activity of this tissue. However, it is also interesting to define the effects of husbandry practices on these parameters, in order to determine the point at which such practices have irreversible effects on milk production. This review will mainly present data concerning ruminants, although in order to describe novel processes, studies involving other species are also reported.

\section{THE NUMBER AND ACTIVITY OF MAMMARY EPITHELIAL CELLS VARY}

\subsection{Importance of the mammary gland size}

For many years, a positive relationship was demonstrated between mammary gland size and milk yield [1]. More recently, a study showed that cows of high genetic merit produced 1.3 times more milk than cows of low genetic merit with 1.3 times more mammary tissue [2]. Rather than udder size, it appears that the "number of mammary cells" is a better determinant fac- tor for milk production. Indeed, it has been shown in the female rat that milk production is better correlated with the number of mammary cells than with mammary gland size [3].

\subsection{Changes in mammary cell number during lactation}

\subsubsection{Acquisition of a production potential at the onset of lactation}

It has long been accepted that in ruminants, after the development of finished tissue prior to parturition, the acquisition of a milk synthesis potential expressed at peak lactation is largely due to an increase in cellular activity. However, mammary growth can occur at the beginning of lactation in some ruminants. Indeed, it has been shown in the goat and cow that the number of mammary cells, estimated by the total quantity of DNA in the udder, rises markedly between the final days of gestation and the first days of lactation ([4], Tab. I), although this is not the case in the ewe ([5], Tab. I). The increase in DNA levels continues during the first weeks of lactation ([6], Tab. I). However, these results are controversial ([7], Tab. I). The acquisition of milk production potential in the udder at the onset of lactation is characterised in particular by a very marked elevation of total RNA levels in the udder. This mainly occurs during the first days of lactation (([5, 7], Tab. II) and may continue over the first weeks ([6], Tab. II. Thus the RNA/DNA ratio increases very

Table I. Total DNA in the mammary gland of several ruminant species before parturition and during early lactation. $\mathrm{L}-\mathrm{i}=$ day $\mathrm{i}$ before lactation; $\mathrm{Lj}=$ lactation day $\mathrm{j}$; Lweek $\mathrm{k}=$ lactation week $\mathrm{k}$.

\begin{tabular}{lcccccc}
\hline Species & $\begin{array}{c}\text { Period } \\
\text { prepartum }\end{array}$ & $\begin{array}{c}\text { DNA } \\
\mathrm{g}\end{array}$ & $\begin{array}{c}\text { Period } \\
\text { early lactation }\end{array}$ & $\begin{array}{c}\text { DNA } \\
\mathrm{g}\end{array}$ & $\begin{array}{c}\text { Period } \\
\text { later lactation }\end{array}$ & $\begin{array}{c}\text { DNA } \\
\mathrm{g}\end{array}$ \\
\hline Cow [4] & L-10 & 27.9 & L10 & 46.0 & - & - \\
Goat [7] & L-5 & 3.1 & L5 & 4.0 & L30 & 3.5 \\
Goat [6] & - & - & Lweek1 & 6.4 & Lweek3 & 7.9 \\
Sheep [5] & L-5 & 2.2 & L10 & 2.3 & - & - \\
\hline
\end{tabular}


Table II. Total RNA in the mammary gland of several ruminant species before parturition and during early lactation. $\mathrm{L}-\mathrm{i}=$ day $\mathrm{i}$ before lactation; $\mathrm{Lj}=$ lactation day $\mathrm{j}$; Lweek $\mathrm{k}=$ lactation week $\mathrm{k}$.

\begin{tabular}{lcccccc}
\hline Species & $\begin{array}{c}\text { Period } \\
\text { prepartum }\end{array}$ & $\begin{array}{c}\text { RNA } \\
\mathrm{g}\end{array}$ & $\begin{array}{c}\text { Period } \\
\text { early lactation }\end{array}$ & $\begin{array}{c}\text { RNA } \\
\mathrm{g}\end{array}$ & $\begin{array}{c}\text { Period } \\
\text { later lactation }\end{array}$ & $\begin{array}{c}\text { RNA } \\
\mathrm{g}\end{array}$ \\
\hline Goat [7] & L-5 & 3.7 & L5 & 7.3 & L30 & 6.5 \\
Goat [6] & - & - & Lweek1 & 12.8 & Lweek3 & 15.3 \\
Sheep [5] & L-5 & 2.4 & L10 & 3.8 & - & - \\
\hline
\end{tabular}

Table III. RNA/DNA ration in the mammary gland of several ruminant species before parturition and during early lactation. $\mathrm{L}-\mathrm{i}=$ day $\mathrm{i}$ before lactation; $\mathrm{Lj}=$ lactation day $\mathrm{j}$; Lweek $\mathrm{k}=$ lactation week $\mathrm{k}$.

\begin{tabular}{lcccccc}
\hline Species & $\begin{array}{c}\text { Period } \\
\text { prepartum }\end{array}$ & $\begin{array}{c}\text { RNA/DNA } \\
\%\end{array}$ & $\begin{array}{c}\text { Period } \\
\text { early lactation }\end{array}$ & $\begin{array}{c}\text { RNA/DNA } \\
\%\end{array}$ & $\begin{array}{c}\text { Period } \\
\text { later lactation }\end{array}$ & $\begin{array}{c}\text { RNA/DNA } \\
\%\end{array}$ \\
\hline Goat [7] & L-5 & 116 & L5 & 184 & L30 & 186 \\
Goat [6] & - & - & Lweek1 & 200 & Lweek3 & 195 \\
Sheep [5] & L-5 & 106 & L10 & 166 & - & - \\
\hline
\end{tabular}

markedly between the final days of gestation and the early days of lactation ([5, 7], Tab. III). This phase allows the organisation of the cell machinery necessary for milk synthesis. It corresponds to the initiation of the massive synthesis of RNA for mammary enzymes specialised in the synthesis of milk components, and of RNA for milk-specific proteins. One study enabled the characterisation of mammary cell activity in the goat udder during lactation. By performing repeated biopsies at the onset of lactation, Knight and Peaker [6] were able to measure the cellular activity of certain enzymes in the gland. When they extrapolated the biopsy data to the entire gland, these authors demonstrated that the increase in milk production at the onset of lactation resulted first of all from an increase in DNA levels, followed by an increase in the enzymatic activity of key enzymes implicated in milk synthesis, such as ACC, FAS and galactosyl transferase (GT). Measurements of lactose and protein synthesis in vitro provided confirmation of the increased activity of mammary epithelial cells at the beginning of lactation [8].

\subsubsection{Changes in the number of mammary cells after peak lactation}

After peak lactation, milk production then gradually declines. This decline is probably due to a gradual reduction in the number of milk-secretory cells. In the cow, between the 90th and 240th days of lactation, it was found that milk production decreased by $23 \%$, and in parallel the quantity of total DNA (and that of epithelial cells) decreased by $17 \%$ [9]. In the goat, milk production and levels of total DNA decreased by $20 \%$ and $19 \%$, respectively, between the 8th and 36th weeks of lactation, while enzyme activities remained at a constant level [6]. The reduction in mammary cell number is the principal process responsible for falling milk yields during the decline of the lactation curve. More precisely, it appears that this decrease particularly affects the number of epithelial cells. Indeed, these cells account for $79 \%$ of mammary tissues at 90 days of lactation, but only $73 \%$ after 240 days [10]. 


\subsection{Mammary cell turnover}

\subsubsection{Proliferation of mammary epithelial cells during lactation}

Changes in the number of cells in the mammary gland during lactation are due to modifications to proliferation and cell death in this organ. Differentiated epithelial cells may have a mitotic configuration in the lactating mammary gland [11], thus proving that these cells are capable of in vivo proliferation. However, cell proliferation is very weak in the lactating mammary gland of the mouse [12] and cow [10]. A study performed in the cow at different stages of lactation and using three different techniques demonstrated that $0.3 \%$ of total cells proliferated, with the rate of proliferation varying little with the stage of lactation [10]. At present, we do not know to which cell types we can attribute this phenomenon. Cell proliferation in the mammary gland may involve stem cells, which retain the ability to divide indefinitely. Such cells have clearly been evidenced in the mammary gland of mice. Indeed, the experimental transplantation of portions of developing or lactating mouse mammary gland has shown that the gland is capable of fully regenerating itself $[13,14]$. Similarly, a mammary gland can be entirely reformed from a single cell transplanted in adipose mammary gland tissue [15]. In the cow, a recent study demonstrated the presence of cells with the same histological characteristics as the stem cells described in the mouse (small, weakly stained cells), exhibiting a mitotic configuration [16]. These cells, declared as being epithelial cells because they possess desmosomes, are present in the bovine mammary gland at all stages of development and during lactation. In addition to these data on stem cells, further studies are necessary to understand how the mammary epithelium renews itself during lactation.

\subsubsection{Death of mammary epithelial cells during lactation}

Cell loss during lactation occurs through programmed cell death, also called apopto- sis. This was first demonstrated during involution in mice [17, 18]. During lactation, only a small proportion of apoptotic cells are present at time $t$ in the mammary gland. The proportion of apoptotic cells in the udders varies considerably, depending on the study, ranging from $2.4 \%$ [19] to $0.07 \%$ [9] in the cow (210-250 days of lactation) and less than $1 \%$ in the goat [20-22] at the end of lactation. The localisation of this process in the udder is controversial; indeed, some authors have sited it more particularly in the alveolar epithelium [19, 23], while others have observed the presence of apoptotic cells in the stroma [21, 24]. One study showed that the distribution of apoptotic cells is heterogeneous. They are probably concentrated within specific alveoli, which are of a regressive type [21]. However, findings to date do not allow us to know whether cell death affects cells always after the same lifespan or if this phenomenon occurs at random.

\subsubsection{Cell turnover in the mammary gland during lactation}

Cell renewal in the mammary gland results from the dual phenomena of proliferation and cell death. Considering a proliferation rate of $0.3 \%$ and that of cell death of $0.56 \%$ per day, not varying during lactation, Capuco et al. [9] made the following calculation: if the cells which die are not those which have proliferated, then $92 \%$ of mammary cells are renewed during lactation. They estimated that if cells could die after proliferating under this hypothesis, then more than half of the cells could renew themselves during a lactation cycle of 240 days. However, these calculations are based on an estimated duration of apoptosis of 3 hours, and this has not been tested experimentally in the mammary gland. The lifespan of a mammary epithelial cell is yet to be calculated. Furthermore, secreting cells are lost through epithelial abrasion during milk ejection, because live mammary epithelial cells are found in milk ([25] for a review). Once again, the relative importance of cell loss by 
evacuation in milk, compared with cell death through apoptosis, has not yet been elucidated.

\subsection{Heterogeneity of the turnover and activity of mammary cells}

Not only is there heterogeneity of cell distribution during apoptosis, but several studies have also demonstrated a heterogeneous functioning of the mammary gland. Through in situ hybridisation, a heterogeneous profile of expression of milk proteins within the mammary epithelium has been demonstrated in the ewe and cow [26]. Milk synthesis activity is not uniform throughout the udder. A histological study performed on mammary glands from lactating ewes and cows demonstrated the presence of specific alveoli containing cells with numerous vacuoles containing lipids and secreting vesicles. Within these alveoli, the lumen exhibited a high content in vesicles [21,27]. This type of alveolus is frequently found in mammary glands after 10 days of involution, suggesting that these specific alveoli are no longer active for milk production. A study in the goat at the end of lactation also demonstrated the existence of two types of alveoli [24]. The first type was made up of clearly differentiated cells containing a rounded nucleus situated close to the basement membrane and apex of secreting vacuoles. The polarisation of these cells was thus evident, and they exhibited a high cytoplasm/nuclear ratio. They were clearly milkproducing alveoli. In contrast, regressing alveoli exhibited cells with a lower cytoplasm/nuclear ratio, an absence of secreting vesicles but the presence of large lipid droplets and occasionally a nucleus which had shifted towards the apical zone. These two relatively recent studies have made it possible to advance the hypothesis that alveoli may exist at different stages of evolution within the mammary gland. A study in the mammary gland of the elephant provides corroboration for this hypothesis. Indeed, the elephant is known for its extremely lengthy period of lactation, so that mammary tissue regeneration in this species raises several questions. Histological analysis of the mammary gland from this animal demonstrated the presence of different types of lobules containing alveoli at different stages of differentiation within lactating tissue [28]. A first type of lobule contained weakly differentiated alveoli containing cells with mitotic configurations, and a second type of lobule containing fully differentiated, milk-secreting alveoli. Finally, a third type of lobule exhibited alveoli containing apoptotic cells. Although this study was performed in a species whose lactation is particularly long, it suggested the possibility of a renewal dynamic for mammary tissue, which could regenerate itself thanks to the formation of new alveoli while other alveoli were beginning to involute.

Thus cell number and cell activity are modified during lactation. We do not understand all the mechanisms underlying these changes. It is, however, acknowledged that husbandry practices can affect milk yield. We review herewith some studies which have demonstrated how husbandry practices can modulate levels of cell activity and cell number in the udder.

\section{HUSBANDRY PRACTICES CAN MODIFY THE ACTIVITY AND NUMBER OF MAMMARY EPITHELIAL CELLS}

\subsection{Genetic}

A comparison of mammary glands in cows from different breeds (Hereford/Holstein) clearly demonstrated that the difference in milk yield $\left(3.5 / 20.3 \mathrm{~kg} \cdot \mathrm{day}^{-1}\right)$ could be explained by changes in the mass and functioning of parenchymatous tissue [29]. Indeed, dairy cows have higher levels of total DNA per udder and a higher number of cells per alveolus than beef cows. In parallel, the total quantity of RNA and the RNA/ DNA ratio is higher in Holstein cattle. Finally, the ability of mammary explants to secrete 
$\alpha$-lactalbumin in culture is greater in dairy cows.

\subsection{Diet}

A study of the effects of diet was performed in heifers receiving feed containing $75 \%$ or $25 \%$ of concentrate during the first eight weeks of lactation. Histological studies showed that mammary cell proliferation was increased by $11 \%$ in animals receiving the high-concentrate diet. Although the rate of apoptosis did not vary significantly, it tended to increase [30]. The quantity of diet ingested could thus modify the number of cells in the udder, given that an increase in ingestion caused an increase in lactation persistency [31]. However, studies of the effects of diet have not always demonstrated any effects on mammary functions. Indeed, in cows receiving a diet deficient in amino acids, no changes were observed to the levels of total DNA, cell proliferation or the activity of key enzymes, whether at the beginning of lactation or at the end [32], even though milk yields were modified.

\subsection{Gestation during lactation}

Most cows are gestating during some part of lactation. After 130 days of gestation, these cows generally produce less milk than non-gestating animals [33, 34]. Changes in milk yield appear to be associated with variations in the balance between apoptosis and proliferation since the number of mammary cells undergoing apoptosis and proliferation increased in pregnant lactating cows (reported by [9]). The negative effect of gestation on milk production occurs towards the end of lactation, at a time when energy demands for foetal growth are increased. This effect coincides with an elevation of plasma oestrogen of foeto-placental origin. This hormone is known to have negative effects on milk production [35]. Moreover oestrogen, known to be involved in mammary development, could also modulate the activity of the mammary gland during lactation. Indeed, injections of oestradiol in mid-late lactating non pregnant cows for 4 days induced a reduction of $\beta$-casein mRNA level in the mammary gland without affecting the mRNA level of genes involved in mammary apoptosis [36]. Thus gestation could modulate both the activity and number of mammary cells.

\subsection{Milking frequency}

\subsubsection{Increase in milking frequency}

Increasing milking frequency from twice to thrice a day has been shown to increase galactopoiesis by 10 to $20 \%$ [37-39]. During the first two weeks after changing over to milking thrice a day, this increase may be accompanied by an elevation in the enzyme activities of ACC, FAS and GT per cell unit, in the goat [40]. Comparable results have been obtained in the cow milked four times a day [41]. However, after 12 weeks, no difference was seen in the enzyme activities of udders milked twice and three times a day. The short-term galactopoietic effect of increasing milking frequency appears to be due to a stimulation of cellular activity. In the longer term, the galactopoietic effect subsequent upon increasing milking frequency seems to be due to a growth of mammary tissue [40, 42]. Indeed, after being milked three times a day for 37 weeks, the increase in milk yield $(+47 \%)$ seemed to be associated with an increase in mammary parenchymatous mass $(+34 \%)$ and DNA levels in the parenchyma $(+23 \%)$, without any changes in enzyme activity [40]. The rise in DNA levels after 37 weeks of treatment was associated with an increase in ${ }^{3} \mathrm{H}$-thymidine uptake $(+27 \%)$, thus demonstrating a stimulation of cell proliferation. In mammary explants from udders milked more frequently, more marked cellular longevity was observed [40]. Comparable results were obtained in cows milked four times a day. Indeed, the mammary tissues of cows milked more frequently exhibited a higher rate of DNA synthesis, associated with an increase in the number of mammary cells [41]. 


\subsubsection{Reduction in milking frequency}

A reduction in milking frequency from twice to once a day has been shown to cause a $10-30 \%$ fall in milk yields in the cow and goat [43-45]. This was associated with changes in the mammary gland structure in the goat [21]. As in the case of increasing milking frequency, its reduction seemed to provoke changes in both cellular activity and cell number. In the cow milked at a rate of one quarter once a day and other quarters twice a day, ACC, FAS and GT enzyme activities were significantly lower in the udders milked only once a day [46]. In the goat, a trend towards a reduction in cellular activity has been observed [45]. Thus, in the goat, after 3 weeks of reducing the milking frequency from twice to once a day, a fragmentation of DNA was observed in the udder, which was characteristic of apoptosis [21]. Changes in the number of mammary cells during modifications of milking frequency were at least partly due to changes in the number of secreting epithelial cells within the alveoli. Indeed, after 23 days of differential milking in the goat (half an udder milked once a day and half an udder milked three times a day), the alveolar diameter was smaller and the number of epithelial cells per alveolus was lower in the halfudders milked less frequently [47]. Moreover milking frequency could modify the total number of alveoli. Two mathematical models explaining the effects of milking frequency on lactation are based on the principle of alveolar dynamics [48, 49]. One of them showed that milking frequency controls the alveolar population [48]. From the second model, they assumed that the senescence rate of alveoli is proportional to the number of quiescent alveoli present [49].

\subsection{Growth hormone treatment}

Treatment with growth hormone $(\mathrm{GH})$ is known to increase milk yield. After one week of treatment, $\mathrm{GH}$ was shown to transiently stimulate the expression of three milk protein genes [50]. This would help to explain why at the beginning of the treat- ment, a secreting cell adjusts its synthetic ability to allow an increase in milk yield. Studies have also been performed on the ability of GH to modify the number of milkproducing cells. The administration of $\mathrm{GH}$ causes an increase in the volume and/or mass of the udder in the cow and goat [47, $51,52]$. It appears that $\mathrm{GH}$ limits progressive cell loss, because after 22 weeks of treatment, the quantity of DNA remained constant in the udders of goats receiving growth hormone, while it diminished in control animals [52]. The effect of GH on the number of mammary cells could be explained more by a proliferative effect than by an effect on their survival. Indeed, at a late stage of lactation, it has been shown that GH stimulates cell proliferation in the cow [9]. Unlike the clearly anti-apoptotic effects of GH and IGF-I (mediating potential GH effects on the mammary gland), demonstrated in vitro [53-55], GH does not cause any changes in the number of apoptotic cells detected by Tunel analysis in the mammary gland [20,24]. At the end of lactation, growth hormone clearly increases mammary gland weight without having any significant effect on the number of epithelial cells in the alveoli, so that GH does not act in the same way as an increase in milking frequency [47]. Rather than acting on the number of cells in the alveoli and on alveolar diameter [47], it appears that GH increases the total number of alveoli, and more particularly that of lactating alveoli [24].

\section{CONCLUSION}

The studies referred to herewith clearly show that regulating the quantity of milk produced involves changes in the level of activity of mammary secreting cells, and also to the cell proliferation/death balance. It appears that changes in cellular activity may intervene at the beginning of the process, either at the initiation of lactation or early on during any changes in milking frequency or treatment with GH. Modifications to the number of mammary cells occur later 
and may have long-term effects on milk yield. It is now clear that the number of epithelial cells within an alveolus, the total number of alveoli and their differentiation status are key determinants of the gland's ability to produce milk. Descriptions of the effects of husbandry practices allow us to envisage different processes for mammary tissue regeneration during lactation. Indeed, milking frequency can modify the number of epithelial cells within an alveolus, while treatment with $\mathrm{GH}$ acts on the total number of alveoli.

It is not as yet clearly defined how mammary cell number declines during lactation. Does this involve the loss of cells within an alveolus, or the loss of entire alveoli? We also still need to understand the role of stem cells in the udder, and to characterise them in ruminants. Finally, it would be interesting to determine the lifespan of a mammary epithelial cell, which could provide valuable information on regulating the persistency of lactation. Characterisation of the parameters which regulate the persistency of lactation constitutes a major challenge for the milk production industry.

\section{ACKNOWLEDGEMENTS}

The authors wish to thank Mrs Victoria Hawken for her assistance in the English translation.

\section{REFERENCES}

[1] Linzell JL. Measurement of udder volume in live goats as an index of mammary growth and function. J Dairy Sci 1966, 49: 307-311.

[2] Sorensen A, Alamer M, Knight CH. Physiological characteristics of high genetic merit and low genetic merit dairy cows: a comparison. In: Proc Br Soc Anim Sci 1998, p 4.

[3] Nagai J, Sarkar NK. Relationship between milk yield and mammary gland development in mice. J Dairy Sci 1978, 61: 733-739.

[4] Tucker HA. Quantitative estimates of mammary growth during various physiological states: a review. J Dairy Sci 1987, 70: 19581966.

[5] Anderson RR. Mammary gland growth in sheep. J Anim Sci 1975, 41: 118-123.

[6] Knight $\mathrm{CH}$, Peaker M. Mammary development and regression during lactation in goats in relation to milk secretion. Q J Exp Physiol 1984, 69: 331-338.

[7] Anderson RR, Harness JR, Snead AF, Salah MS. Mammary growth pattern in goats during pregnancy and lactation. J Dairy Sci 1981, 64: 427-432.

[8] Knight CH, Wilde CJ. Mammary growth during lactation: implications for increasing milk yield. J Dairy Sci 1987, 70: 1991-2000.

[9] Capuco AV, Wood DL, Baldwin R, McLeod $\mathrm{K}$, Paape MJ. Mammary cell number, proliferation, and apoptosis during a bovine lactation: relation to milk production and effect of bST. J Dairy Sci 2001, 84: 2177-2187.

[10] Capuco AV, Akers RM, Smith JJ. Mammary growth in Holstein cows during the dry period: quantification of nucleic acids and histology. J Dairy Sci 1997, 80: 477-487.

[11] Franke WW, Keenan TW. Mitosis in milk secreting epithelial cells of mammary gland: an ultrastructural study. Differentiation 1979, 13: $81-88$.

[12] Traurig HH. A radioautographic study of cell proliferation in the mammary gland of the pregnant mouse. Anat Rec 1967, 159: 239247.

[13] Deome KB, Fauklin LJ Jr, Bern HA, Blair PB. Development of mammary tumors from hyperplastic alveolar nodules transplanted into gland-free mammary fat pads of female C3H mice. Cancer Res 1959, 19: 515-520.

[14] Smith GH, Medina D. A morphologically distinct candidate for an epithelial stem cell in mouse mammary gland. J Cell Sci 1988, 90: 173-183.

[15] Kordon EC, Smith GH. An entire functional mammary gland may comprise the progeny from a single cell. Development 1998, 125: 1921-1930.

[16] Ellis S, Capuco AV. Cell proliferation in bovine mammary epithelium: identification of the primary proliferative cell population. Tissue Cell 2002, 34: 155-163.

[17] Quarrie LH, Addey CV, Wilde CJ. Programmed cell death during mammary tissue involution induced by weaning, litter removal, and milk stasis. J Cell Physiol 1996, 168: 559569. 
[18] Strange R, Li F, Saurer S, Burkhardt A, Friis RR. Apoptotic cell death and tissue remodelling during mouse mammary gland involution. Development 1992, 115: 49-58.

[19] Wilde CJ, Addey CV, Li P, Fernig DG. Programmed cell death in bovine mammary tissue during lactation and involution. Exp Physiol 1997, 82: 943-953.

[20] Boutinaud M, Flament-Ginard J, Jammes H. Analysis of gene expression involved in mammary cell death; a clue to the milk potential of the mammary gland. $10^{\mathrm{e}}$ Rencontres Recherches Ruminants, Paris, 3-4 dec 2003, p 49-52.

[21] Li P, Rudland PS, Fernig DG, Finch LM, Wilde CJ. Modulation of mammary development and programmed cell death by the frequency of milk removal in lactating goats. $J$ Physiol 1999, 519 Pt 3: 885-900.

[22] Wareski P, Motyl T, Ryniewicz Z, Orzechowski A, Gajkowska B, Wojewodzka U, Ploszaj T. Expression of apoptosis-related proteins in mammary gland of goat. Small Rumin Res 2001, 40: 279-289.

[23] Capuco AV, Akers RM. Mammary involution in dairy animals. J Mammary Gland Biol Neoplasia 1999, 4: 137-144.

[24] Baldi A, Modina S, Cheli F, Gandolfi F, Pinotti L, Scesi LB, Fantuz F, Dell'Orto V. Bovine somatotropin administration to dairy goats in late lactation: effects on mammary gland function, composition and morphology. J Dairy Sci 2002, 85: 1093-1102.

[25] Boutinaud M, Jammes H. Potential uses of milk epithelial cells: a review. Reprod Nutr Dev 2002, 42: 133-147.

[26] Molenaar AJ, Davis SR, Wilkins RJ. Expression of alpha-lactalbumin, alpha-S1-casein, and lactoferrin genes is heterogeneous in sheep and cattle mammary tissue. J Histochem Cytochem 1992, 40: 611-618.

[27] Molenaar AJ, Kuys YM, Davis SR, Wilkins RJ, Mead PE, Tweedie JW. Elevation of lactoferrin gene expression in developing, ductal, resting, and regressing parenchymal epithelium of the ruminant mammary gland. J Dairy Sci 1996, 79: 1198-1208.

[28] Welsch U, Feuerhake F, van Aarde R, Buchheim W, Patton S. Histo- and cytophysiology of the lactating mammary gland of the African elephant (Loxodonta africana). Cell Tissue Res 1998, 294: 485-501.

[29] Keys JE, Capuco AV, Akers RM, Djiane J. Comparative study of mammary gland development and differentiation between beef and dairy heifers. Domest Anim Endocrinol 1989, 6: 311-319.
[30] Sorensen A, Sorensen MT, Andersen JB, Ingvartsen K.L., Serjrsen K. Effect of milking frequency and diet on mammary development in lactating dairy cows. Abstract of the 51st Annual Meeting of European Association for Animal production 2000, p 234.

[31] Sorensen A, Knight CH. Effect of milking frequency, nutrition and calving season on lactation persistency. Abstract of the 51st Annual Meeting of European Association for Animal production 2000, p 219.

[32] Yeo JM, Knight CH, Chamberlain DG. Effects of changes in dietary amino acid balance on milk yield and mammary function in dairy cows. J Dairy Sci 2003, 86: 1436-1444.

[33] Lee JK, VanRaden PM, Norman HD, Wiggans GR, Meinert TR. Relationship of yield during early lactation and days open during current lactation with 305-day yield. J Dairy Sci 1997, 80: 771-776.

[34] Roche JR. Effect of pregnancy on milk production and bodyweight from identical twin study. J Dairy Sci 2003, 86: 777-783.

[35] Peaker M, Linzell JL. The effects of oestrus and exogenous oestrogens on milk secretion in the goat. J Endocrinol 1974, 61: 231-240.

[36] Delbecchi L, Miller N, Petitclerc D, Lacasse $P$. Induction of milk yiles decrease and mammary gland involution in lactating Holstein cows and female rates. J Dairy Sci 2002, Suppl 1: 85 .

[37] Amos HE, Kiser T, Loewenstein M. Influence of milking frequency on productive and reproductive efficiencies of dairy cows. J Dairy Sci 1985, 68: 732-739.

[38] Campos MS, Wilcox CJ, Head HH, Webb DW, Hayen J. Effects on production of milking three times daily on first lactation Holsteins and Jerseys in Florida. J Dairy Sci 1994, 77: 770-773.

[39] Knight CH. Milk yield responses to sequential treatments with recombinant bovine somatotropin and frequent milking in lactating goats. J Dairy Res 1992, 59: 115-122.

[40] Wilde CJ, Henderson AJ, Knight CH, Blatchford DR, Faulkner A, Vernon RG. Effects of long-term thrice-daily milking on mammary enzyme activity, cell population and milk yield in the goat. J Anim Sci 1987, 64: 533-539.

[41] Hillerton JE, Knight CH, Turvey A, Wheatley SD, Wilde CJ. Milk yield and mammary function in dairy cows milked four times daily. $\mathrm{J}$ Dairy Res 1990, 57: 285-294. 
[42] Henderson AJ, Blatchford DR, Peaker M. The effects of long-term thrice-daily milking on milk secretion in the goat: evidence for mammary growth. Q J Exp Physiol 1985, 70: 557565.

[43] Carrurthers VS, Davis SR, Norton DH. The effect of oxytocine and bovine somatotropin on production of cows milked once a day. Proc NZ Soc Anim Prod 1991, 51: 197-201.

[44] Lynch GA, Hunt ME, Mackenzie DDS. The effects of once daily milking as a practice in late lactation. Proc NZ Soc Anim Prod 1991, 51: 191-195.

[45] Wilde CJ, Knight CH. Milk yield and mammary function in goats during and after oncedaily milking. J Dairy Res 1990, 57: 441-447.

[46] Farr VC, Stelwagen K, Kerr MA, Davis SR, Eichler SJ. Effect of once daily milking (ODM) on enzyme activities in the bovine mammary gland. Proc NZ Soc Anim Prod 1995, 55: 12-13.

[47] Boutinaud M, Rousseau C, Keisler DH, Jammes H. Growth hormone and milking frequency act differently on goat mammary gland in late lactation. J Dairy Sci 2003, 86: 509-520.

[48] Shorten PR, Vetharaniam I, Soboleva TK, Wake GC, Davis SR. Influence of milking frequency on mammary gland dynamics. J Theor Biol 2002, 218: 521-530.

[49] Vetharaniam I, Davis SR, Soboleva TK, Shorten PR, Wake GC. Modeling the interaction of milking frequency and nutrition on mammary gland growth and lactation. J Dairy Sci 2003, 86: 1987-1996.

[50] Boutinaud M, Rulquin H, Keisler DH, Djiane J, Jammes H. Use of somatic cells from goat milk for dynamic studies of gene expression in the mammary gland. J Anim Sci 2002, 80: 1258-1269.

[51] Capuco AV, Keys JE, Smith JJ. Somatotrophin increases thyroxine-5'-monodeiodinase activity in lactating mammary tissue of the cow. J Endocrinol 1989, 121: 205-211.

[52] Knight CH, Fowler PA, Wilde CJ. Galactopoietic and mammogenic effects of longterm treatment with bovine growth hormone and thrice daily milking in goats. J Endocrinol 1990, 127: 129-138.

[53] Geier A, Beery R, Haimsohn M, Karasik A. Insulin-like growth factor-1 inhibits cell death induced by anticancer drugs in the MCF-7 cells: involvement of growth factors in drug resistance. Cancer Invest 1995, 13: 480-486.

[54] Goh EL, Pircher TJ, Wood TJ, Norstedt G, Graichen R, Lobie PE. Growth hormoneinduced reorganization of the actin cytoskeleton is not required for STAT5 (signal transducer and activator of transcription-5)-mediated transcription. Endocrinology 1997, 138: 3207-3215.

[55] Goh EL, Pircher TJ, Lobie PE. Growth hormone promotion of tubulin polymerization stabilizes the microtubule network and protects against colchicine-induced apoptosis. Endocrinology 1998, 139: 4364-4372. 